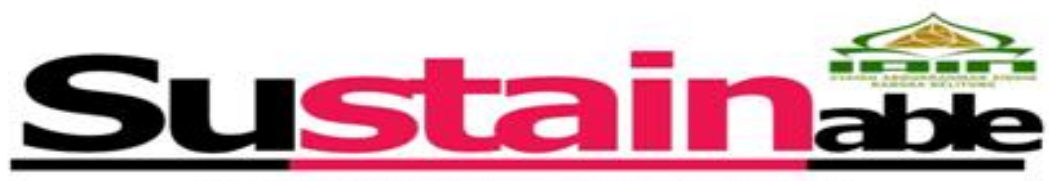

Jurnal Kajian Mfutu Pendidikan

LPM IAIN Syaikh Abdurrahman Siddik Bangka Belitung

https://jurnal.Ip2msasbabel.ac.id/index.php/sus ISSN 2655-0695 (Online)

\title{
Using Anagram Technique to Develop Students' Vocabulary Mastery to the Seventh Grade Students
}

\author{
Indrawati', Febya Resty ${ }^{2}$
}

${ }^{12}$ IAIN Syaikh Abdurrahman Siddik Babel, Indonesia

Keywords:

Anagram Technique

Vocabulary Mastery

Keywords:

Teknik Anagram

Penguasaan kosakata

\begin{abstract}
The research problems of this study were (1) to find out the application of anagram technique in improving student's vocabulary mastery and (2) to know whether there was a significant difference in vocabulary mastery between the experimental group where the anagram technique was implemented and the control group which no treatment was given during the experiment. In this study, the writer used the quantitative method with quasi experimental group design. The samples of this study consisted of 36 students of VII E as Experimental Group and 36 students of VII F as Control Group taken from the second year students of seven classes of MTs N Pangkalpinang. The result of the test was analyzed by using statistical analysis of Paired sample t-test and Independent sample t-test. Based on the result analysis, there were two major findings, namely (1) the implementation of Anagram technique in developing students' vocabulary mastery was successful and the result of difference analysis in post-test of experimental and control group showed that the value of t-obtained was 3.488 which was higher than t-table 2.03 (at the significant level $\mathrm{p}<0.05$ in two tailed testing with degree of freedom 7o). The result of this study showed when the means of the post tests between the two classes were compared, the post-test scores were better than the pre-test scores (43.31)for the experimental group (8o.89).
\end{abstract}

\begin{abstract}
Abstrak
Rumusan masalah dalam penelitian ini adalah (1) untuk mengetahui penerapan teknik anagram dalam meningkatkan penguasaan kosakata siswa dan (2) untuk mengetahui apakah terdapat perbedaan yang signifikan penguasaan kosakata antara kelompok eksperimen tempat penerapan teknik anagram dan kelompok eksperimen. kelompok kontrol yang tidak diberikan perlakuan selama percobaan. Dalam penelitian ini penulis menggunakan metode kuantitatif dengan rancangan kelompok eksperimen semu. Sampel penelitian ini terdiri dari 36 siswa kelas VII E sebagai kelompok eksperimen dan 36 siswa kelas VII F sebagai kelompok kontrol yang diambil dari siswa tahun kedua kelas tujuh MTs N Pangkalpinang. Hasil pengujian dianalisis dengan menggunakan analisis statistik Paired sample t-test dan Independent sample t-test. Berdasarkan hasil analisis terdapat dua temuan utama yaitu (1) penerapan teknik Anagram dalam pengembangan penguasaan kosakata siswa berhasil dan hasil analisis perbedaan post-test kelompok eksperimen dan kelompok kontrol menunjukkan bahwa nilai t -dapatkan 3,488 lebih tinggi dari t-tabel 2,03 (pada taraf signifikan $\mathrm{p}<0,05$ pada pengujian dua sisi dengan derajat kebebasan 70). Hasil penelitian ini menunjukkan bahwa nilai rata-rata post test antara kedua kelas dibandingkan, nilai post test lebih baik daripada nilai pre test $(43,31)$ untuk kelompok eksperimen $(80,89)$.
\end{abstract}

Korespondensi

Indrawati, indrawati.fr@gmail.com 


\section{Introduction}

In this modern era, people should have more than one language to be mastered (Indrawati, 2019; Marzulina et al., 2019; Mukminin et al., 2018). One of the most to be taught language at schools in Indonesia is English (Lie, 2017). The students should deal with English lesson starting when they are in Elementary School, Junior and Senior High School, even in university classes (Yusny, 2013). As a reason of fact, English becomes an international language that should be mastered Indonesian people (Abduh \& Rosmaladewi, 2019). Language is a mean used to communicate to other people as prime part in everyday life (Gultom, 2015). People communicate in foreign languages for different purposes; gaining knowledge and information as well as learning the cultures (Sulistiyo, 2016). Practically, in communication, vocabulary mastery is very important in negotiation of meaning when the students become speakers or listeners, readers or writers. Fluency in a language can be developed through communication with comprehension of the meaningful of words (Erlina et al., 2019; Indrawati, 2018; Richards, 2013). The students who are lack of vocabulary knowledge, it will be difficult for them to communicate to other people.

Based on Basic Competence, the seventh grade students should develop aspect of English for all skills; reading, writing, speaking and listening (Suryani, 2018). The format of individual assessments are more on vocabulary (Suryani, 2018). In Junior high school students must have 1000 vocabulary a year as their vocabulary (아창학, 2007). It means that they learn from six to eight new words each day. That is an enormous achievement (Firda, Widiati, Laksmi, \& Hayati, 2018). Mastering a large number of vocabularies is very important for foreign language learners. If students know more vocabulary, it will be easy for them to learn another aspect of English language. Vocabulary is also an important language element to achieve in comprehension. It means that a communication never occur without having good vocabulary mastery.

Based on Oxford English Dictionary (Oxford, 2010), vocabulary is defined as "All the words in a language, list of words and their meaning especially in a book used for learning a foreign language". According to Richard and Renandya, "Vocabulary is a core component of language proficiency and provides much of the basis for how well learners speak, listen, read, and write." It means that vocabulary covers all the aspect of english language when the students will be speaker or listener, reader or writer through interaction in English communication (Richards, 2011).

According to Lynne Cameron (Cameron, 2001), "Vocabulary development is about much more than that. Vocabulary development is also about learning more about those words, and about learning formulaic phrases or chunks, finding words inside them, and learning even more about those words." Keith S. Folse stated, "English language learners need to increase their vocabulary knowledge. Given the time constraints of many learners, teachers should incorporate explicit vocabulary teaching supported by classroom activities that reinforce previously studied material (Folse, 2008). While Jack. C. Richards argued that, "Vocabulary is one of the most obvious components of language and one of the first thing applied linguists to need their attention to (Richards \& Schmidt, 2010)"

Based on the explanation above, the writer can state that if students have good knowledge in comprehending the meaningful of words in vocabulary, it will be easy for them to conduct good communication. If the students have little comprehension of the vocabulary, they will be difficult to communicate with other people. Then, the students must be able to develop their vocabulary mastery supported by technique in vocabulary teaching (Mukminin et al., 2015).

By developing the students' mastery of vocabulary, they will be able to read, understand and comprehend the text and memorize words. By providing them fun techniques, strategies, and approaches in teaching vocabularies, students will be motivated to know more about the new language they learn (Yurtbașı, 2015). Learning vocabulary makes the students easy to share their ideas about the meaning of the words.

According to Margie Golick, "Anagrams are always fun. The typical anagram task is to rearrange the letters in a word using all of its letters, and only those letters, to make another word" (Rosadi, 2017). Anagram is without adding of other letters. Practically, anagram technique can help the student to producing another word (I Wayan Dirgayasa Tangkas, 2014). Moreover, that it can develop their vocabulary mastery. Anagram technique may also giving some clues based on the definition or meaning of the words in the different order and asking the students to complete vocabulary task (Sinaga, Herman, \& Pasaribu, 2020). In addition, anagram gives the students chances to producing another word and practice about words on the basic of given clue.

The writer used text to help the implementation of Anagram technique. According to Scott Thornbury, "The tendency is to present vocabulary in text. Text are ideal for classroom use (Thornbury, 2007). In other words, texts are rich in vocabulary learning. The writer focused on vocabulary in the descriptive text. The vocabulary often used in descriptive text is word which is related to those things. Descriptive text is the text that used based on the syllabus for the seventh grade students at MTs Negeri Pangkalpinang.

The researcher focused on vocabulary based on the word classes especially for nouns, verbs and adjectives in descriptive text according to syllabus of seventh grade students at MTs Negeri 
Pangkalpinang. The topics of the text are 1.) Describing people's physical appearance, classmates characteristics and occupation, 2.) things in the classroom, kitchen and living room, 3.) animals in environment, animals in my home, animals in my school and 4.) public places. There are some factors of vocabulary mastery such as word meaning, extending word use, word combinations, the grammar of words and spelling (Abrar et al., 2018; Al-Furqon, 2017; Indrawati, 2017). In this study, the researcher focused on word meaning and spelling the right words.

Related to the description above, “Using Anagram Technique to Develop Students' Vocabulary Mastery to the Seventh Grade Students of MTs Negeri Pangkalpinang in Academic Year 2016-2017" might be an interesting topic to be explored. The researcher used anagram technique to develop students' English achievement, especially in vocabulary mastery and the application of anagram technique in teaching vocabulary.

Based on the background of the study, the problems of this study can be formulated as the following:

1. How is the implementation of anagram technique to develop students' vocabulary mastery to the seventh grade students of MTs Negeri Pangkalpinang in academic year 2016-2017?

2. Is there any significant difference in vocabulary mastery of anagram technique between the students who are taught by using anagram technique and those who are taught by non-anagram technique?

\section{Research Method}

\section{The Procedure of Anagram Technique}

The procedure of teaching in this research used alphabet letters, worksheet and on the whiteboard. According to Bruce Marsland, there were procedures in teaching vocabulary by using anagram, as follows (Marsland, 1998):

1. Compile a list of about some anagrams using words from teacher's chosen vocabulary set.

2. Write these anagrams on the whiteboard.

3. Set a time limit for groups to try to discover all the answers.

4. Emphasise that you will not accept answers to individual questions. For example: untape/ peanut, garden/danger, tea/eat, gallery/allergy, listen/silent, asleep/please, mug/gum, chair/a rich/, earn/near, smile/slime, bedroom/boredom.

According to Julia Murphy, there are some steps in teaching vocabulary by using anagram technique are as follow (Lunsford \& Murphy, 1989) :

1. Provide them with anagrams of some of the vocabulary.

2. Write anagrams on the board, and ask for the delegation student from each group to puzzle them out.

3. Some pupils will be able to do this very quickly.

4. The next stage is for them to prepare a crossword-type clue for each word.

5. These clues can then be used to help those for whom word puzzles are not a strong point.

An example of this could be the pupils studying the Victorians who have already solved the anagrams of the words, 'slums', 'suburbs', 'overcrowding', 'disease' and 'poverty'. Encourage them to think of clues to each word that would have those struggling to unscramble the letters of the anagram. For 'disease' they might just say 'cholera and TBC are examples of this', or create a more sophisticated clue if they are more able.

An anagram can be formed from a phrase. There really is no limit to what words, phrases can rearrange. The most important thing that make an anagram must use all the letters. (Lunsford \& Murphy, 1989) Anagram is each of the original words provided by your teacher can be arranged to make another word.

1. As a whole group, do one or more additional examples together.

2. Provide students with a list of words that can be rearranged to form other words.

3. Students work in pairs to solve the anagrams.

4. Provide guidance as students are working together.

Use only the letters provided in the original word to create new word. Anagrams can be used before reading (Blachowicz \& Fisher, 2016).

Hint: Each new word will be an animal. Good luck!

Examples of Anagram Technique

\begin{tabular}{|l|l|}
\hline Original Words & New Word \\
\hline Act & Cat \\
\hline Flow & Wolf \\
\hline Bare & Bear \\
\hline
\end{tabular}

There is also of anagram technique is anagram pair. Anagram pair is anagram activities into rhymes. The rhymes itself can act as a clue to one of anagram pair (Rosadi, 2017). Moreover, Joseph Leeming states that anagram riddles is found by turning around the letters of the first word to form the second. 
1. Can you turn around a short sleep and get a kitchen utensil? Nap-.......... (answer: pan)

2. Can you turn around wicked and get wide-awake?

Evil-........... (answer: live)

It means that anagram pair and anagram riddles may also give clues based on the definition or meaning of the words in the different order and ask the students to complete vocabulary task. In conclusion, the writer used anagram technique to develop students' vocabulary mastery to the seventh grade of MTs N Pangkalpinang.

Anagram can give the students enjoyment or challenge in studying vocabulary and encourage them to look carefully at words, students can practice to form other words from the given clues, students may also give clues based on the definition or meaning of the words in the wrong order and asking the students to complete vocabulary task, students spell the word correctly to make another word or new vocabulary, show the students how the letters of many words can be manipulated to form other words, emphasize the importance of letter position in relation to word meaning. Anagram technique can help the students to focus on spelling as well as meaning or definition.

On the procedure of teaching in this research, the writer made three kinds of activities. It can be done in groups, in pair, or in individual. For the individual activity, the student who can complete it first is the winner and gets the good point from the teacher. In pair work or group, for each correct word as well as clue or definition would be given a star as a reward. The teacher counted the number of star the students have got (Vossoughi \& Zargar, 2009). All of the winners would be given prizes from the researcher. It makes these activities to be more attractive.

\section{The Implementation of Anagram Technique}

Based on the steps above, the writer used descriptive text based on the syllabus to help the anagram technique. The topics of the text are people, things, animals, and public places. The writer made the implementation of Anagram technique to develop students' vocabulary mastery to the seventh grade students that consist of 36 students. A variety of interesting and enjoyable activities provides through individual student practice, role-plays, pair activity and whole class activities and enables learners to apply the language they learn . The writer made three kinds of activities; group activity, pair activity and individual activity.

\section{a. Group Activity}

First, the writer explained briefly what is Anagram Technique. The writer grouped the students in the class into four groups and one delegation student to each group. The delegation from each group must come in front of the class. Each group compiled a list of about some anagrams used words from teacher's chosen vocabulary set in the descriptive text by alphabet letters. After that, the each group discussed the topic to write an anagram for each word as well as clue and definition. The writer guided the students to discuss their answer. The delegation from each group prepared crossword-type clue for each word on the whiteboard. Then, they gave clues and definition from each word that had been made into an anagram for their delegation student. The clue should be used to help the delegation of each group to made an anagram from each word and writed some anagrams on the whiteboard. Writer corrected their answer together. For each correct word, the writer gave a star as a reward. At last, the writer counted the number of star that the students had got. All of the winners had prizes from the teacher.

\section{b. Pair Activity}

First, the writer explained briefly what Anagram Technique is. As a whole group, did one or more additional example together. The writer provided with a list of words that should be rearranged to form other words in the descriptive text by used alphabet letters. The writer asked the students to made the class into pairs. Next, the writer distributed the anagram worksheet to each pair students. Students made an anagram for each word in anagram worksheet to completed the descriptive text with an anagram and the writer asked students to identified clue or definition from each word that had been made into an anagram. The writer provided guidance as students worked together. Then, the writer corrected their answer together. For each correct word should be given a star as a reward. The writer counted the number of star that the students had got. All of the winners had prizes from the teacher.

\section{c. Individual Activity}

In the beginning, the writer explained briefly what is Anagram Technique and distributed the anagram worksheet. Students made an anagram for each word in anagram worksheet to completed the descriptive text with an anagram based on the clue and definition in the anagram pair worksheet by alphabet letters. Then, the writer corrected their answer together. The students who should completed the anagram worksheet first was the winner and got the good point from the writer.

The teaching steps for experimental group were as follows (Asril, 2017):

\section{Pre-Activities}

a) Greet 
b) Pray before study

c) Check the attendance list

d) Review the previous lesson

e) Warm up (create atmosphere in the classroom through asking questions which related to the materials of teaching).

\section{Whilst Activities}

a) Explanation about the lesson

b) Explain briefly what is Anagram technique

c) The implementation of Anagram technique

\section{Post Activities}

a) Evaluation of the teaching through assessment (teacher reviews the vocabulary as well as definition or meaning that the students have got)

b) Closing

\section{The Advantages of Anagram Technique}

The anagram is a kind of word play that is used by teacher to give students practice in meaning of the words and spelling. The students spell the word correctly to make another word or new vocabulary (Keshta, 2013). The students may also giving some clues based on the definition or meaning of the words in the wrong order and asking the students to complete vocabulary practice (Sinaga et al., 2020; Sulistianingsih, Juliani, \& Pradjarto, 2020). In other word, anagram technique can help the students to focus on spelling as well as meaning. The anagram task can be used to focus on vocabulary in the post reading condition from the text (Chamot, 1998). In addition, anagram is a good technique to develop students' vocabulary in reading comprehension.

\section{The Method of Research and Research Design}

In this study, the writer attempted to conduct research entitled "Using Anagram Technique to Develop Students' Vocabulary Mastery to The Seventh Grade Students of MTs Negeri Pangkalpinang in Academic Year 2016-2017". For this study, the writer used quantitative approach. In this research, the writer gave the pre-test to experimental and control group. The writer taught both of groups $2 \times 40$ minutes for each meeting. The whole meeting was 14 meeting consists of 2 meetings for pre-test and post-test and 12 meetings for teaching and learning process. The implementation of anagram technique was conducted to the experimental group, while for the control group were taught by using non-anagram technique. After that, the writer gave the post-test for both of the groups.

\section{The Population and Sample of the Study} this study.

In this session the writer presented the population and sample as a source in collecting the data of

\section{Population of the Study}

The population of the study consisted of all the seventh grade students at the MTs Negeri Pangkalpinang in academic year 2016-2017. The total number of students were 240 students.

Table 1

Population of the Study

\begin{tabular}{|l|l|l|}
\hline No. & Class & Total \\
\hline 1. & VII A & 36 \\
\hline 2. & VII B & 36 \\
\hline 3. & VII C & 36 \\
\hline 4. & VII D & 36 \\
\hline 5. & VII E & 36 \\
\hline 6. & VII F & 36 \\
\hline 7. & VII G & 24 \\
\hline Total & 240 \\
\hline \multicolumn{2}{|l|}{ Source: MTs Negeri Pangkalpinang } \\
\hline
\end{tabular}

\section{Sample of the Study}

In this research, the writer used non-random sampling specifically purposive sampling in taking the sample.

Purposive sampling means that technique of determining the sample is based on the specific purpose (Hamid Darmadi, 2014). There were some considerations in choosing the sample of this study; (1) the teacher of English subjects at the seventh grade students of MTs Negeri Pangkalpinang asked the writer to use VII E and VII F as the sample of study, (2) the samples of this research were VII E and VII F students, because many of students got the daily 
tests score below 50 among the other classes, (3) the result of pre-test between VII E and VII F students, in which the average score of both class in VII E got 41,58 and VII F got 62,8 (See appendix B and C). Based on the consideration above, the writer took class VII E and VII F as the samples. Then, the writer determined VII E as the experimental group and VII F as the control group.

Table 2

The Samples of Study

\begin{tabular}{|l|l|l|l|l|l|}
\hline No. & Group & Class & Men & Women & Sample \\
\hline 1. & The experimental group & VII E & 16 & 20 & 36 \\
\hline 2. & The control group & VII F & 15 & 21 & 36 \\
\hline \multicolumn{7}{|c|}{ Source: MTs Negeri Pangkalpinang } & $\mathbf{7 2}$ \\
\hline
\end{tabular}

\section{The technique for Collecting the Data}

The writer had three kinds of techniques for collecting the data consisting of observation, test and documentation.

\section{Observation}

In observation, the writer observed the students activities in teaching process from the beginning up to the end. Nunan and Bailey propose that observation was viewed to relate procedures for gathering data during actual activities (Nunan, 2004). he purpose of the observation in this study was for investigating the implementation of anagram technique in the classroomm. In collecting the data, the writer used observation. It means that there was an interaction between the writer and the respondents. There were three indicators of the observation in this research such as attendance, attention, students' activeness in asking and answering question during the teaching process and doing all the activities (Nunan, 2012).

2. Test

The writer used a test in the vocabulary. Test is the tools for measuring an individuals' knowledge or skill in a given area or subject (Wallen \& Fraenkel, 2001). The test given by the writer to the students of control and experimental group were pre test and post test. These tests were given in order to know the students' ability in vocabulary mastery.

\section{Documentation}

The writer used documentation as evidence to clarify the result of research. The data was collected during the implementation of anagram technique to the seventh grade students at MTs Negeri Pangkalpinang. Thus, in this research, the writer used syllabus, lesson plan, student's score, student's attendance list and photos.

\section{Findings and Discussion}

This section describes and analyzes the result of the experimental group and control group.

\section{a. The Result of Observation in the Experimental Group}

In this study, the observation was applied by the writer to know the implementation of Anagram Technique in Experimental Group. In the process of learning, there were four indicators to be observed. They were attendant list, attention, activeness in asking and answering question, and cooperation in doing all the activities.

Table 3

The Observation in the Experimental group

\begin{tabular}{|c|c|c|c|c|c|c|c|c|}
\hline \multirow[b]{2}{*}{$\sum_{\Sigma}^{\infty}$} & \multicolumn{2}{|c|}{ Attendance } & \multicolumn{2}{|c|}{ Attention } & \multicolumn{2}{|c|}{$\begin{array}{l}\text { Activeness } \\
\text { (Asking and } \\
\text { answering } \\
\text { Question) }\end{array}$} & \multicolumn{2}{|c|}{$\begin{array}{l}\text { Cooperation } \\
\text { (Doing all the } \\
\text { activities) }\end{array}$} \\
\hline & $\underset{\stackrel{n}{*}}{\stackrel{n}{0}}$ & 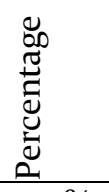 & 荀 & 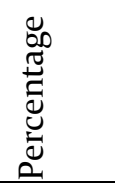 & 苞 & 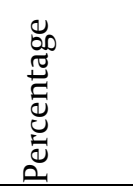 & 营 & 品 \\
\hline $1^{\text {st }}$ & 36 & $100 \%$ & 32 & $88.8 \%$ & 31 & $86.1 \%$ & 34 & $94.4 \%$ \\
\hline $2^{\text {nd }}$ & 35 & $97.2 \%$ & 33 & $91.6 \%$ & 20 & $55.5 \%$ & 28 & $77.7 \%$ \\
\hline $3^{\text {rd }}$ & 32 & $88.8 \%$ & 27 & $75 \%$ & 18 & $50 \%$ & 29 & $83.3 \%$ \\
\hline $4^{\text {th }}$ & 35 & $97.2 \%$ & 22 & $61.1 \%$ & 26 & $72.6 \%$ & 31 & $86.1 \%$ \\
\hline $5^{\text {th }}$ & 35 & $97.2 \%$ & 24 & $66.6 \%$ & 27 & $75 \%$ & 32 & $88.8 \%$ \\
\hline $6^{\text {th }}$ & 35 & $97.2 \%$ & 30 & $83.3 \%$ & 30 & $83.3 \%$ & 31 & $86.1 \%$ \\
\hline $7^{\text {th }}$ & 35 & $97.2 \%$ & 32 & $88.8 \%$ & 22 & $61.1 \%$ & 30 & $83.3 \%$ \\
\hline $8^{\text {th }}$ & 35 & $97.2 \%$ & 27 & $75 \%$ & 20 & $55 \cdot 5 \%$ & 29 & $80.5 \%$ \\
\hline
\end{tabular}




\begin{tabular}{|l|l|l|l|l|l|l|l|l|}
\hline $9^{\text {th }}$ & 35 & $97.2 \%$ & 35 & $97.2 \%$ & 26 & $72.2 \%$ & 30 & $83.3 \%$ \\
\hline $10^{\text {th }}$ & 33 & $91.6 \%$ & 31 & $86.1 \%$ & 28 & $77.7 \%$ & 31 & $86.1 \%$ \\
\hline $11^{\text {th }}$ & 36 & $100 \%$ & 36 & $100 \%$ & 34 & $94.4 \%$ & 36 & $100 \%$ \\
\hline $12^{\text {th }}$ & 36 & $100 \%$ & 32 & $88.8 \%$ & 29 & $80.5 \%$ & 36 & $100 \%$ \\
\hline $13^{\text {th }}$ & 36 & $100 \%$ & 36 & $100 \%$ & 34 & $94.4 \%$ & 36 & $100 \%$ \\
\hline $14^{\text {th }}$ & 36 & $100 \%$ & 36 & $100 \%$ & 36 & $100 \%$ & 36 & $100 \%$ \\
\hline
\end{tabular}

The result of the table observation above could be read as a scale of valued in the following table:

Table 4

The Category of Percentage

\begin{tabular}{|l|l|}
\hline Scale & Category \\
\hline $85 \%-100 \%$ & Very Good \\
$69 \%-84 \%$ & Good \\
$53 \%-68 \%$ & Average \\
$<53 \%$ & Low \\
\hline
\end{tabular}

Source: https://saidnazulfikar.files.wordpress.com/2011/10/skripsi-audio-lingual-in-teaching-speaking.pdf

Based on the table above, the aspect of attendance of the students from the first to the fourteenth meetings were in very good category. There were some students absent, it was because of sick, permitted, and without any information. From the aspect of attention, it could be seen that the percentage of the first, second, seventh, ninth, tenth, eleventh, twelfth, thirteenth and fourteenth meetings were in very good category. Meanwhile, in the third, sixth, and eighth meetings were in good category. Then, for the fourth and fifth meeting, it was showed that the students' attention were in average category.

The third aspect was the students' activeness. In this aspect, it could be seen that the percentage of the first, eleventh, thirteenth and fourteenth meetings were in very good category. Then, fourth, fifth, sixth, ninth, tenth and twelfth meetings were in good category. Meanwhile, the second, seventh and eight meetings were in average category, except the third meeting which was in low category.

Furthermore, the last aspect was cooperation (doing all the activities). In this aspect, it showed that the percentage of the first, fourth, fifth, sixth, tenth, eleventh, twelfth, thirteenth and fourteenth meetings were in very good category, except the second, third, seventh, eighth and ninth meetings which were in good category.

\section{b. The Result of Observation in the Control Group}

In this study, the observation was applied by the writer to know the implementation of Anagram Technique in Experimental Group. In the process of learning, there were four indicators to be observed. They were attendant list, attention, activeness in asking and answering question, and cooperation in doing all the activities.

Table 5

The Observation in the Control Group

\begin{tabular}{|c|c|c|c|c|c|c|c|c|}
\hline \multirow[b]{2}{*}{ 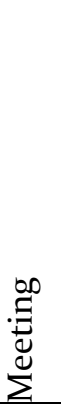 } & \multicolumn{2}{|c|}{ Attendance } & \multicolumn{2}{|c|}{ Attention } & \multicolumn{2}{|c|}{$\begin{array}{l}\text { Activeness } \\
\text { (Asking and } \\
\text { answering } \\
\text { Question) }\end{array}$} & \multicolumn{2}{|c|}{$\begin{array}{l}\text { Cooperation } \\
\text { (Doing all the } \\
\text { activities) }\end{array}$} \\
\hline & 旁 & 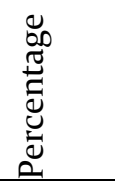 & 葛 & O্口 & 苞 & 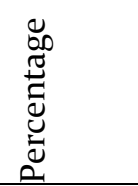 & 苞 & 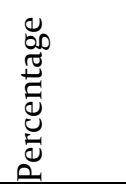 \\
\hline $1^{\text {st }}$ & 36 & $100 \%$ & 34 & $94.4 \%$ & 34 & $94.4 \%$ & 34 & $94.4 \%$ \\
\hline $2^{\text {nd }}$ & 36 & $100 \%$ & 26 & $72.2 \%$ & 20 & $55 \cdot 5 \%$ & 22 & $61.1 \%$ \\
\hline $3^{\text {rd }}$ & 32 & $88.8 \%$ & 28 & $77.7 \%$ & 28 & $77.7 \%$ & 26 & $72.2 \%$ \\
\hline $4^{\text {th }}$ & 36 & $100 \%$ & 23 & $63.8 \%$ & 28 & $77.7 \%$ & 23 & $63.8 \%$ \\
\hline $5^{\text {th }}$ & 36 & $100 \%$ & 28 & $77.7 \%$ & 35 & $97.2 \%$ & 28 & $77.7 \%$ \\
\hline $6^{\text {th }}$ & 36 & $100 \%$ & 30 & $83.3 \%$ & 14 & $38.8 \%$ & 31 & $86.1 \%$ \\
\hline $7^{\text {th }}$ & 33 & $91.6 \%$ & 21 & $58.3 \%$ & 20 & $55 \cdot 5 \%$ & 28 & $77.7 \%$ \\
\hline $8^{\text {th }}$ & 36 & $100 \%$ & 26 & $72.2 \%$ & 21 & $58.3 \%$ & 28 & $77.7 \%$ \\
\hline $9^{\text {th }}$ & 36 & $100 \%$ & 35 & $97.2 \%$ & 29 & $80.5 \%$ & 33 & $91.6 \%$ \\
\hline $10^{\text {th }}$ & 36 & $100 \%$ & 29 & $80.5 \%$ & 30 & $83.3 \%$ & 30 & $83.3 \%$ \\
\hline $11^{\text {th }}$ & 36 & $100 \%$ & 32 & $88.8 \%$ & 30 & $83.3 \%$ & 32 & $88.8 \%$ \\
\hline $12^{\text {th }}$ & 36 & $100 \%$ & 30 & $83 \cdot 3 \%$ & 23 & $63.8 \%$ & 29 & $80.5 \%$ \\
\hline $13^{\text {th }}$ & 36 & $100 \%$ & 31 & $86.1 \%$ & 28 & $77.7 \%$ & 29 & $80.5 \%$ \\
\hline $14^{\text {th }}$ & 36 & $100 \%$ & 36 & $100 \%$ & 31 & $86.1 \%$ & 36 & $100 \%$ \\
\hline
\end{tabular}

The result of the table observation above could be read as a scale of valued in the following table: 
Table 6

The Category of Percentage

\begin{tabular}{|l|l|}
\hline Scale & Category \\
\hline $85 \%-100 \%$ & Very Good \\
$69 \%-84 \%$ & Good \\
$53 \%-68 \%$ & Average \\
$<53 \%$ & Low \\
\hline
\end{tabular}

Source: https://saidnazulfikar.files.wordpress.com/2011/10/skripsi-audio-lingual-in-teaching-speaking.pdf

Based on the table above, the aspect of attendance of the students from the first to the fourteenth meetings were in very good category. There were some students absent, it was because of sick, permitted, and without any information. From the aspect of attention, it could be seen that the percentage of the first, ninth, eleventh, thirteenth and fourteenth meetings were in very good category. Meanwhile, in the second, third, fifth, sixth, eighth, tenth and twelfth meetings were in good category. Then, for the fourth and seventh meetings, it was showed that the students' attention were in average category.

The third aspect was the students' activeness. In this aspect, it could be seen that the percentage of the first, fifth, and fourteenth meetings were in very good category. Then, third, fourth, ninth, tenth, eleventh and thirteenth meetings were in good category. Meanwhile, the second, seventh, eight and twelfth meetings were in average category, except the sixth which was in low.

Furthermore, the last aspect was cooperation. In this aspect, it showed that the percentage from the first, sixth, ninth, eleventh and fourteenth meetings were in very good category. Then, third, fifth, seventh, eighth, tenth, twelfth and thirteenth were in good category. Meanwhile, the second and fourth were in average category.

\section{Discussion}

In this section the writer presented the interpretation of observation and the interpretation of comparative analysis result. After doing observation, the writer found out that most of students who were taught by using anagram technique were enthusiastic and interested in learning process. There were four aspects of observation assessed by the writer: students' attendance, students' attention, and students' interaction and students' cooperation in doing all the activities.

Besides, the writer interpreted that Anagram Technique could develop students' vocabulary mastery and motivation in learning English lesson, especially to the seventh grade students of MTs Negeri Pangkalpinang. The writer could see that the students were enthusiastic, because they learned by using unusual way when teaching and learning process. Most of the students were high interest in following the lesson through Anagram Technique judging from how active they were when joining the learning activities.

Anagram Technique has been proved effective to help the students understand the spelling and definition or meaning of the word easily during teaching and learning activities. Anagram Technique could gave the students enjoyment or challenge in studying vocabulary and encourage them to look carefully at words, students can practice to form other words from the given clues, students also give clues based on the definition or meaning of the words in the wrong order and asking the students to complete vocabulary task, students spelled the word correctly to make another word or new vocabulary, showed the students how the letters of many words could be manipulated to form other words, emphasize the importance of letter position in relation to word meaning. Anagram technique could help the students to focus on spelling as well as meaning or definition. Since they were enthusiastic to join the activities, it would make them remember the words and the meaning easily.

Based on the result of the observation, most of the students were very good in every activity. Therefore, the writer found out that by using anagram technique, it could make the students motivated and interested in learning especially in developing their vocabulary mastery. There were advantages in using Anagram technique based on my observation such as:

1. The students could enjoy or feel challenge in studying vocabulary (when the students discussed to make an anagram as well as clue and definition for each word that underlined based on the text. The students prepared crossword type clue for each word on the whiteboard by the delegation from each group and part of each group give clues and definition from each word that has been made into an anagram for their delegation student. The clue can be used to help the delegation of each group to make an anagram from each word and writes some anagrams on the whiteboard).

2. The students could remember the words and the meaning easily (when the students completed the text with anagram based on the definition and clue in the anagram pair worksheet by alphabet letters).

3. The students could focus on spelling of the word as well as meaning. 
After doing the experiment in teaching vocabulary by using anagram technique, the writer interpreted that there was a significant difference in vocabulary achievement between the students who were taught by using anagram technique and the students who were taught by using non-anagram technique.

The result of paired differences between pre-test and post-test in experimental group showed the value of t-obtained was higher than t-table (21.34>2.03). Meanwhile, the result of paired differences between pre-test and post-test in control group showed the value of t-obtained (4.877) was higher than t-table (2.03). The significant ( 2 tailed) was lower than computation with level significant $(0.000<0.05)$, it could be stated that there was a significant difference in students' vocabulary mastery before and after the treatment.

From the result of statistical analysis showed that the mean of pre-test in the experimental group was 43.31 and the mean of pre-test of control group was 63.19 while, the mean of post-test in the experimental group was 80.89 and the mean of post-test in the control group was 72.86 . It means that after getting treatment the mean of post-test of experimental group was higher than control group. It showed that the students had progress in vocabulary achievement.

In addition, based on the result of the test, the writer found that the students who were taught by using anagram technique got better vocabulary mean score in experimental group than control group. It can be seen from the vocabulary mean score such as noun ( from 4,72 to 9,44), verb ( from 3,75 to 4,30 ), adjective ( from 2,80 to 7,22 ) and mean of gain score $(37,5)$ in experimental group which was higher than the vocabulary mean score in the control group such as noun ( from 7,11 to 8,16), verb ( from 4,61 to 5,22), adjective ( from 4,75 to 5,58 ) and mean of gain score $(11,16)$.

So, there was a significant difference in vocabulary achievement between students who were taught and they were not taught by Anagram Technique. Therefore, the alternative hypothesis $(\mathrm{Ha})$ is accepted and null hypothesis (Ho) is rejected.

\section{Conclusions}

After performing the study entitled Using Anagram Technique to Develop Students Vocabulary Mastery to the Seventh Grade Students of MTs Negeri Pangkalpinang in Academic Year 2016-2017, the writer tried to infer the conclusions based on the research problems.

Based on the process of the implementation of anagram technique in experimental group, the result of the research could conclude that the students who were taught by using anagram technique were able to identify and find out the meaning of the vocabulary which used to comprehend the text. It was known from the process of teaching and learning activities; most of students could enjoy, remember and understand the meaning of the word easily. It was seen from the aspect of attention, activeness, and cooperation; the students were in 'very good' and 'good' category. From the result of observation, it can be concluded that anagram technique could develop the students' vocabulary knowledge.

Furthermore, statistical analysis of the test during the experiment, the writer could conclude that the teaching of vocabulary using anagram technique could help students in developing their vocabulary mastery. Based on the result of the test, the students who were taught by using Anagram technique got better score on their post-test than their pre-test. It can be seen from the mean score (8o.89) of the posttest in experimental group which was higher than the mean score (43.31) of the pre-test in experimental group.

The value of t-obtained was higher than t-table paired sample difference between pre-test experiment and post-test experiment (4.877>2.03), and t-table paired sample difference between pre-test control and post-test control (21.34>2.03) and the significant ( 2 tailed) was lower than computation with level significant $(0.000<0.05)$, it could be stated that there was a significant difference in students' vocabulary mastery before and after the treatment in experimental group. Then, from the result of comparative analysis of independent sample t-test showed that there was a significant difference in their post-test score between students who were taught by using Anagram technique and the students who were taught without using Anagram technique. It could be seen from the mean score (8o.89) of post-test in experimental group which was higher than the mean score $(72.86)$ of the post-test in control group. Thus, it can be inferred that the null hypothesis was rejected and the research hypothesis was accepted. Consequently, Anagram is one of the ways in developing students' vocabulary mastery.

\section{References}

Abduh, A., \& Rosmaladewi, R. (2019). Language policy, identity, and bilingual education in Indonesia: A historical overview. XLinguae. https://doi.org/10.18355/XL.2019.12.01.17

Abrar, M., Mukminin, A., Habibi, A., Asyrafi, F., Makmur, M., \& Marzulina, L. (2018). "If our English isn't a language, what is it?" Indonesian EFL Student Teachers' Challenges Speaking English. Qualitative Report.

Al-Furqon, A. S. (2017). THE EFFECT OF WORD SEARCH PUZZLE GAME IN TEACHING VOCABULARY TO THE FIRST GRADESTUDENTS OF SMPN 3 PROPPO. WACANA DIDAKTIKA. https://doi.org/10.31102/wacanadidaktika.v5io2.25 
Asril, Z. (2017). Micro Teaching disertai dengan Pedoman Pengalaman Lapangan, Jakarta: PT. Raja Grafindo Persada.

Blachowicz, C. L. Z., \& Fisher, P. (2016). Vocabulary instruction. In Handbook of Reading Research. https://doi.org/10.4324/9781351217347-4

Cameron, L. (2001). Teaching Languages to Young Learners. Teaching Languages to Young Learners. https://doi.org/10.1017/cbo9780511733109

Chamot, A. (1998). Teaching Learning Strategies to Language Students. Professional Preparation of Teaching Assistants in Foreign Languages.

Erlina, D., Marzulina, L., Astrid, A., Desvitasari, D., Sapriati, R. S., Amrina, R. D., ... Habibi, A. (2019). Linguistic intelligence of undergraduate EFL learners in higher education: A case study. Universal Journal of Educational Research. https://doi.org/10.13189/ujer.2019.071012

Firda, I. D. L., Widiati, U., Laksmi, E. D., \& Hayati, N. (2018). ATTITUDES TOWARD EXTENSIVE READING AMONG ENGLISH TEACHERS OF SENIOR HIGH SCHOOLS. Jurnal Ilmu Pendidikan. https://doi.org/10.17977/umo48v24i1p1-9

Folse, K. S. (2008). Six Vocabulary Activities for the English Language Classroom. English Teaching Forum.

Gultom, E. (2015). English Language Teaching Problems in Indonesia. 7th International Seminar on Regional Education.

Hamid Darmadi. (2014). Metode Penelitian Pendidikan dan Sosial. In Metode Penelitian Pendidikan dan Sosial.

I Wayan Dirgayasa Tangkas, S. M. A. (2014). IMPROVING STUDENTS' VOCABULARY ACHIEVEMENT BY APPLYING ANAGRAM PLUS FLASHCARDS AT THE SMP NEGERI 7 PEMATANGSIANTAR. REGISTER Journal of English Language Teaching of FBS-Unimed. https://doi.org/10.24114/reg.v3i2.1130

Indrawati, I. (2017). My Insights on Learning Modern English Grammar. Tarbawy : Jurnal Pendidikan Islam. https://doi.org/10.32923/tarbawy.v4i1.812

Indrawati, I. (2018). Improving Tadris Bahasa Inggris Students' Competency of Curriculum Development in Language Education through Investigating SMU Teachers' Perceptions on the Implementation of 2013 Curriculum. Tarbawy : Jurnal Pendidikan Islam. https://doi.org/10.32923/tarbawy.v5i2.837

Indrawati, I. (2019). Motivation and Confidence of Pre-Service Teachers to Use English as Medium of Instruction during Teaching Practicum. Edugama: Jurnal Kependidikan Dan Sosial Keagamaan. https://doi.org/10.32923/edugama.v5i2.966

Keshta, A. S. (2013). The Effectiveness of Using Puzzles in Developing Palestinian Tenth Graders' Vocabulary Achievement and Retention. Humanities and Social Sciences. https://doi.org/10.11648/j.hss.20130101.16

Lie, A. (2017). ENGLISH AND IDENTITY IN MULTICULTURAL CONTEXTS: ISSUES, CHALLENGES, AND OPPORTUNITIES. TEFLIN Journal. https://doi.org/10.15639/teflinjournal.v28i1/71-92

Lunsford, A. A., \& Murphy, J. J. (1989). Quintilian on the Teaching of Speaking and Writing. College Composition and Communication. https://doi.org/10.2307/358137

Marsland, B. (1998). Lessons from Nothing. Lessons from Nothing. https://doi.org/10.1017/cbo9780511733147

Marzulina, L., Mukminin, A., Erlina, D., Astrid, A., Ajriyah, N., Holandiyah, M., \& Habibi, A. (2019). The grammatical awareness of student teachers: The case of an english education study program in Indonesia. Universal Journal of Educational Research. https://doi.org/10.13189/ujer.2019.070902

Mukminin, A., Haryanto, E., Sutarno, S., Sari, S. R., Marzulina, L., Hadiyanto, \& Habibi, A. (2018). Bilingual education policy and Indonesian students' learning strategies. Elementary Education Online. https://doi.org/10.17051/ilkonline.2018.466330

Mukminin, A., Masbirorotni, M., Noprival, N., Sutarno, S., Arif, N., \& Maimunah, M. (2015). EFL Speaking Anxiety among Senior High School Students and Policy Recommendations. Journal of Education and Learning (EduLearn). https://doi.org/10.11591/edulearn.v9i3.1828

Nunan, D. (2004). Task-Based Language Teaching. Task-Based Language Teaching. https://doi.org/10.1017/cbo9780511667336

Nunan, D. (2012). Learner-centered English language education: The selected works of David Nunan. Learner-Centered English Language Education: The Selected Works of David Nunan. https://doi.org/10.4324/9780203096888

Oxford, D. E. (2010). Oxford Learner's Dictionary.

Richards, J. C. (2011). Theories of Teaching in Language Teaching. In Methodology in Language Teaching. https://doi.org/10.1017/cbo9780511667190.004

Richards, J. C. (2013). Curriculum approaches in language teaching: Forward, central, and backward design. RELC Journal. https://doi.org/10.1177/o033688212473293

Richards, J. C., \& Schmidt, R. (2010). Longman Dictionary of Language Teaching \& Applied Linguistics. Proceedings of the 21st Asian Pacific Weed Science Society (APWSS) Conference, 2-6 October 2007, Colombo, Sri Lanka.

Rosadi, A. (2017). The Effectiveness of Anagram Technique in Teaching Vocabulary. VELES Voices of English Language Education Society. https://doi.org/10.29408/veles.vii1.392

Sinaga, H., Herman, H., \& Pasaribu, E. (2020). THE EFFECT OF ANAGRAM GAME ON STUDENTS' 
VOCABULARY ACHIEVEMENT AT GRADE EIGHT OF SMP NEGERI 8 PEMATANGSIANTAR. Journal of English Educational Study (JEES). https://doi.org/10.31932/jees.v3i1.655

Sulistianingsih, E., Juliani, R. D., \& Pradjarto, T. (2020). THE EFFECT OF ANAGRAM GAMES ON SECONDARY LEVEL STUDENTS' READING ACHIEVEMENT. JOALL (Journal of Applied Linguistics E Literature). https://doi.org/10.33369/joall.v5i1.8763

Sulistiyo, U. (2016). English Language Teaching and Efl Teacher. Iselt-4.

Suryani, R. W. (2018). "WHEN ENGLISH RINGS THE BELL": An English Textbook Analysis. English Language Teaching and Research.

Thornbury, S. (2007). How to teach speaking. Longman.

Vossoughi, H., \& Zargar, M. (2009). Using Word-Search-puzzle Games for Improving Vocabulary Knowledge of Iranian EFL Learners Archive. Journal of Teaching English as a Foreign Language and Literature of Islamic Azad University of Iran.

Wallen, N. E., \& Fraenkel, J. R. (2001). Educational research: A guide to the process, 2nd ed. Educational research: A guide to the process, and ed.

Yurtbaşı, M. (2015). Building English vocabulary through roots, prefixes and suffixes. Global Journal of Foreign Language Teaching. https://doi.org/10.18844/gjflt.v5io.39

Yusny, R. (2013). ELT IN INDONESIAN CONTEXT: Issues and Challenges. Englisia Journal. https://doi.org/10.22373/ej.vii1.140

이창학. (2007). Teaching Vocabulary through Anagram. The Journal of Studies in Language. https://doi.org/10.18627/jslg.22.3.200702.259 